\title{
BESPREKING EN GESPREK
}

I. SENDING IN MEERVOUD, bespreek in „In die Skriflig", Febr./Maart 1969, verkrygbaar by N.G. Kerk. boekhandel, Posbus 245, Pretoria.

THE CHRISTIAN MESSAGE TO A CHANGING WORLD, International reformed bulletin, Official organ of the international Association for reformed faith and action, Number 35, 11th Year, October 1968, Conference papers, Res Baarn Missions Conference 1968, s.b., 133 bl. Verkrygbaar by dr. I. J. van der Walt, Molenstraat 21, Potchefstroom, @ 95c.

Die konferensie te Baarn, Nederland van 5 tot 8 Augustus, is gereël deur die Kommissie vir Sending van die Geref. Ekumeniese Sinode. Daar was 23 Gereformeerde gemeenskappe uit 6 kontinente en 15 lande verteenwoordig rondom die tema: The Christian Message to a Changing World. Die sentrale probleem was: Hoe kan die Skriftuurlike, historiese Christelike geloof betekenis kry vir die behoeftes van die moderne, gesekulariseerde mens?

John P. Galbraith het gepraat oor Not since the Reformation, en aangetoon dat die ongeloof, die geleenthede en die noodsaaklikheid vir 'n alles-omvattende poging 'n unieke hoogtepunt bereik het. Prof. Shingeru Yoshioka van Japan het in sy voordrag, The Goal of Missions, die koms en uitbreiding van die koninkryk van God voorop gestel in teëstelling met die liberale ideaal wat sending in diens stel van Westerse beskawing en internasionale broederskap. Die koms van die koninkryk word gesoek in God se heerskappy in die hart, die kerk en die wêreld. Hy waarsku teen die institusionalisme wat sending meet aan die uitwendige groei van die kerk en beklemtoon die organiese en organisatoriese aspekte van aie kerk. Lidmaatskap aan die kerk moet die geestelike eenheid met Christus manifesteer. Die heerskappy van God moet verder strek as die sigbare kerk. Hy het aangetoon dat piëtisme en revivalisme in Japan ' $n$ jammerlike kloof tussen die evangelie en teisme geslaan het.

Ds. P. E. S. Smith van die N.G. Kerk het gehandel oor The evangelizing Church amidst growing secularism Die momentum van die proses is vandag waarneembaar op wetenskaplike, tegnologiese, ekonomiese en demografiese terreine. Hy gee besonder aandag aan die Christelike rewolusie in Afrika en die bedreiginge wat die moderne liberale teologie inhou om die kerk op mars te versmoor. Die sendende kerk moet op Bybelse grondslae vernuut word, anders word dit ' $n$ blote dimensie van nasionale of sosiale lewe.

Dr. D. C. Mulder van die V.U., Amsterdam, het oor World Mission and Syncretism gespreek, 'n verskynsel wat opduik wanneer die nuwe godsdiens die ou lewe binnedring of invloede uit die lewe die evan. 
gelie kleur. Sinkretisme moet onderskei word van sinkretistiese elemente. Hy onderskei 'n Asiatiese, Afrika- en Westerse sinkretisme. Die sendeling moet onderskei tussen die evangelie en sy Westerse gewaad en ekumeniese kontakte met die separatistiese kerke soek. Dit lyk gedwonge wanneer hy in hierdie verband juis die pogings van die Christelike Instituut van C. F. B. Naudé roem. „Ecumenism in Evangelism" is behandel deur ds. J. W. Deenick van Australië, vanuit die oogpunt van die eenheid en universaliteit van die kerk van Christus. Hy lê nadruk op die eenheid in leer as basis vir effektiewe eenheid, betwyfel die "eenheid" wat soms in die blote samewerking tussen biskop en biskop of sinode en sinode gelees word. Samewerking tussen gelowiges is meer effektief as dié tussen denominasies. Gevolglik raai hy Christelike samewerking deur middel van non-denominasionale aksies, inter-kerklike aksies en laastens deur kerkvereniging aan. In die woorde van biskop Dain betwyfel hy die voordele van kerkvereniging met die oog op verenigde aksie in sending, omdat nuwe probleme eerder ' $n$ verlam. mende uitwerking het. Hy sê: ,... there is no shortcut to a genuinely biblical unification of the church of Christ. Organizational unity based on little else but the desire to be one and not rooted in genuine agreement as to what the message of the church is for today is as illusory as it is frustrating" (p. 57). Net so min as wat afskeiding 'n oplossing bied vir elke kwaal in die kerk, kan eenheid dit gee.

Die voordrag van dr. M. L. Young van Tennessee oor die verhouding van The National Church and the Foreign Mission is m.i. besonder geslaagd. Dit gaan oor die vraag hoe die vreemde sending moet optree wanneer die nasionale kerk selfregerend, selfonderhoudend en selfuitbreidend geword het. Hy meen dat die sending nie slegs op grond van Matth. 28 : 18-20 gemotiveer moet word nie, maar van die verbond moet uitgaan. Die werkverbond (Gen. 2) wat hy liefs die „covenant of life" noem, sluit aan by Gen. $1: 28$. Die genadeverbond na die val (Gen. $3: 15$ ) is moontlik te veel soteriologies beperk, sodat die kultuuropdrag van die werkverbond op die agtergrond raak. "Is not the cultural task God imposes on man as his mission in life a basic element of the covenant of life in which man is shown not only the way to avoid death ... but also the way to live, that is what that obedience entailed by way of a goal and task?" (p. 65). Hierdie oorspronklike roeping het bly staan en Matth. 28 : 18-20 moet dus vertolk word in die lig van hierdie verbond. Sending moet dus gedoen word sodat die mens God sal dien in die uitvoering van sy kultuuropdrag. Dissipels moet ook diensknegte van God wees. Op die sendingveld word primêr dissipels gemaak, by voorkeur moet dan eers 'n huisgemeente aan huis van 'n vooraanstaande lidmaat gebou word (p. 69). Oorbeklemtoning van selfregering, selfonderhouding en selfuitbreiding en die nasionale, maak die kerk doel op homself, wat selfs in 'n kerk met weinig geestelike lewe verwesenlik kan word. Hy wys aan die ander kant op die gevare wanneer die sendende kerk steeds die rekenings bly betaal. Gevolglik bepleit hy dat die sendende kerk in 'n broederlike verhouding (eerder as ' $n$ vader-kind-verhou- 
ding) die selfstandige inheemse kerk moet stimuleer om die kultuuropdrag op opvoedkundige, landbou, mediese en ander terreine na te kom. „Religion is a total way of life and all life is religion" (p. 74).

Ds. Robert Recker van Grand Rapids het The Church's Mission Programme aangedui, ' $n$ artikel wat baie kante aansny, maar m.i. telkens dreig om in algemeenhede weg te sweef van die eintlike probleme. Miskien is die artikel te min prinsipieel en te veel pragmaties opgesit.

Prof. Hugo du Plessis van Potchefstroom het Consolidating Reformed Missions behandel en aangetoon dat die Gereformeerde sending op prinsipiële punte van die res van Christendom verskil. Daar is ' $n$ behoefte aan eenheid te midde van ' $n$ kleinerwordende wêreld en die drang om identiteite te handhaaf. Die Gereformeerde sendingaktiwiteite het 'n roeping teenoor mekaar en teenoor die ontwikkelende volke, 'n taak teenoor die wêreld en teenoor die res van die Christendom. Hy bepleit dan 'n konsolidasie van sending in die komprehensiewe verband van die doel van God met sy koninkryk en hy gee riglyne hoe dit teweeggebring kan word ten opsigte van pastoraat en sending, litteratuur en massa-kommunikasie-media, onderwys en mediese dienste, diakonaat, "leke"-arbeiders, verandering van macrostrukture, opleidingsentra, ens. Hy meen dat die Geref. Ekumeniese Sinode met 'n versterkte sekretariaat in hierdie opsig 'n groot taak het.

Ten slotte druk dr. P. G. Schrotenboer 'n kragtige esgatalogiese noot in sy "Missions and the Consummation", waarin hy die erns van die huidige tydsgewrig in die lig van die volheid van die tyd stel. Die toekoms beheers die hede.

Dit is duidelik dat ons in hierdie uitgawe die besinning het van Gereformeerde teoloë wat met mekaar in Baarn oor sending kon gepraat het op 'n gemeenskaplike basis van een belydenis. Hierdie referate moet gelees en bestudeer word deur elke Gereformeerde wat vandag met gesag oor die sending wil praat. Die artikel van $M$. L. Young verdien veral ernstige oorweging met die oog op die praktiese benadering van die sending.

Pretoria, 1969.

B. Spoelstra.

\section{OPENBARINGSGESKIEDENIS VAN DIE OU TES.}

TAMENT, Vierde hersiene en uitgebreide druk, Pro Rege-Pers, Beperk, Potchefstroom, 1969.

Die eerste druk van hierdie boek het in 1962 verskyn, die tweede en derde in afgerolde vorm in 1967 en 1968 . Hierdie vierde bevat belangrike uitbreidings op die eerste (en selfs die derde). Die boek bied nou byna dubbel soveel stof as vroeër. Nog belangriker is egter dat waar dit vantevore in 'n mate kompendiumagtig was, dit nou ' $n$ mooi eenheid vorm en in ' $n$ baie groot mate aan openbaringshistoriese „vaartbelyning" gewen het. Hierdie boek is 'n mylpaal 
in die Afrikaanse teologie, en hoewel dit beskeie aangebied word „vir studente en onderwysers in Bybelstudie”, kan dit met groot vrug in die teologiese studie gebruik word. 'n Woord van hartlike gelukwense aan die skrywer; ook aan die uitgewers vir die stewige en sierlike aanbieding.

Prof. Du Toit wys die leser die weg te midde van die groot verskeidenheid menings, en openbaar 'n fris siening op sake. Hy slaag veral daarin om 'n mens iets van die grootsheid van die Heilige Skrif en die grootheid van God te laat aanvoel. In hierdie opsig is die indrukwekkende Sinaiberg op die stofomslag tekenend van die inhoud.

Die skrywer gee eers aandag aan die gesag van die Bybel en bied onder meer 'n handige kernagtige historiese oorsig oor die Skrifverklarings. Dis formeel egter hinderlik dat Die Reformasie 'n onderdeel vorm van Dwaalweë van die Skrifverklaring - al laat die bespreking geen twyfel oor die skrywer se positiewe waardering van dié tyd nie. 'n Ander indeling kan die besondere betekenis en insnyding van die Reformasie seker beter tot sy reg laat kom.

Die skrywer bespreek ook die verhouding van Skrif en Belydenis en lê veral daarop klem dat die Skrif per slot van sake die hoogste en laaste gesag is. Hy waarsku ook tereg daarteen dat 'n mens die Belydenis deur jou eie bril lees. Die bespreking van die gesag van die Belydenis is egter onduidelik en verwarrend. Al is die volgende $\sin$ aan $H$. Bavinck ontleen, roep dit in die bespreking hier (vgl. bls. 12, 13) meer vrae op as wat dit beantwoord: „Die belydenis word aanvaar omdat en in sover dit met die Skrif ooreenstem". Hoe moet dit gerym word met die ondertekeningsformulier vir ampsdraers wat die ondertekenaar aan die Belydenis bind omdat dit met die Skrif ooreenstem? Selfs die sin op bls. $35 \mathrm{klaar}$ nie hierdie onduidelikheid op nie: „Die Skrifverklaarder moet dus terdeë rekening hou met die Skrifverklaring wat in die Belydenis voorkom".

Die onderskeid tussen Openbaringsgeskiedenis, Gewyde geskiedenis en Dogmatiek word behandel. Hier sou ons graag ook die onderskeid met die Geskiedenis van Israel en die Godsdiens van Israel wou verneem het.

Die boek volg ,'n middeweg tussen die horisontale en vertikale metodes", d.w.s. histories volgens periodes enersyds en volgens temas andersyds. Die eerste bevredig myns insiens die meeste, hoewel die beoefening van die vak nog baie probleme moet uitstryk. Die tweede metode leun te veel op die Dogmatiek en te min op dissiplines van die Openbaringsgeskiedenis self. Hoewel hierdie vierde uitgawe meer bevredig, is dit ook die hoofkritiek wat teen die tweede deel van die boek ingebring kan word, vergelyk bv. hoofstuk XIX: Die weldade van die genadeverbond - die weg van die heil (via salutis).

Die hoofgedagte wat voorop gestel word is: Die koninkryk van God. Tereg word gesê: „Die O.T. stel in die kern van sy verkondiging die verwagting van die koninkryk van God" (bls. 48). Hier word soms mooi verbande gelê. As by ander 'n sterker 
organiese verbandlegging tussen hooftema en inhoud uitgebou kon word, sou dit die waarde van die werk baie verhoog. As die persoonlike gemeenskap tussen God en mens - wat bv. by Vriezen soveel klem ontvang - meer aandag kry, kan dit die boek aan aktualiteit laat toeneem. Ook die verbondsgedagte kan 'n veel sentraler plek kry.

Anders as J. Bright wat 'n mens in sy boek „The Kingdom of God", in een opsig in die steek laat, naamlik daarin dat hy eers met Abraham begin, trek prof. Du Toit die lyn deur tot Gen. 1 : 1. Met die oog op die bespreking van die eerste hoofstukke van Genesis bied hy die leser eers sy sleutel vir die verklaring. Dit is behartenswaardig as hy met klem voorop stel dat die Skrif homself moet verklaar, dat Skrif en Skrif alleen moet spreek en dat die besondere doel van die Skrif baie duidelik in die oog gehou moet word. Dit wil nie Wetenskap of gewone Geskiedenis gee nie. 'n Argument e silentio sluip egter in waar hy motiveer waarom die Bybel nie gewone geskiedenisbeskrywing gee nie: „Dan moet die konklusie aanvaar word: omdat die profane geskiedenis ons niks sê van Abraham en Moses nie, is die verhale oor hulle onhistories!"

Prof. Du Toit staan 'n „profetiese” verklaring voor. Soos wat die profete historiese stof aan hulle doel ondergeskik maak en (her)rangskik sodat kronologiese en logiese orde soms vermeng raak, so is dit ook met die "historiese boeke" wat eweneens in profetiese gees geskryf is. Die profetiese blik sien sowel die toekomstige as antieke dinge vanuit die verte. Daarom moet daar 'n ooreenkoms wees in die verklaringsmetode van esgatologie en protologie onderskeidelik. Hierdie verklaringsmetode van prof. Du Toit het beslis iets aantrekliks en kan ook sekere probleme uit die weg ruim. Daarom sou dit goed wees as hy die motivering daarvan kon uitbou. Daar is byvoorbeeld die wesenlike probleem dat die esgatologiese stof duidelik 'n ander stylsoort aanneem wanneer dit met sake anderkant die horisonte te doen het, waar in die proto-logiese stof dit juis nie die geval is nie. Is daar dan nie, vanuit literêre oogpunt, meer te sê vir die beskouing van Van Selms (of ook Kroeze?) dat ons hier met verhaalstyl te doen het nie?

Die "menslike aspek" in die openbaring word duidelik en sterk na vore gebring. Die stellinge oor die "wêreldbeeld" van die Bybelskrywers is egter minder duidelik. Ons sou byvoorbeeld meer klem op die Goddelike voorbeskikking van die menslike instrumente en hulle plasing in die openbaringshistoriese raamwerk verwelkom.

Tussen Gen. 1 en 2 sien die skrywer ,'n verskil in ,klimaat' ", die een is sistematies-skools, die ander kinderlik-eenvoudig. Die histories-profetiese siening reken hier met tydrekenkundige sowel as logiese orde. Dit kom, soos by 'n skildery, aan op die geheel. indruk. Die skrywer verwerp die vergeestelikende verklaring van Barth wat alles Christo-monisties sien. Die skrywer van Genesis wil volgens hom vir ons werklik iets sê oor dinge wat werklik gebeur 
het, al is dit dan in historiese beligting en geen gewone geskiedenis nie. Dit wil 'n antwoord gee op die vraag na die oorsprong van alle dinge, maar het tog bowenal 'n religieus-etiese betekenis (bls. 55, 56).

Prof. Du Toit verwerp ook die sogenaamde kaderhipotese soos voorgestaan deur A. Noordtzij en N. H. Ridderbos, waarvolgens die ses dae van Gen. 1 'n kader of skema is waarin die skrywer sy gedagtes meedeel. Hy meen dat Gen. 1 nie die minste aanduiding gee dat die dae so verstaan moet word nie en dat dit strydig is met die vierde gebod - dit bly dan maar 'n voorstelling asof God sy werk in sewe dae gedoen het. Hy vereenselwig hom met Aalders se siening dat hier "dae van God" bedoel word wat korter of langer as ons dae kon geduur het. Hy het dus blykbaar afgesien van sy vroeëre „teleskopiese" beskouing waarvolgens baie agtereenliggende dae tot een dag gefokus is.

Tohu wabohu (,woes en leeg") word deur die skrywer verklaar as aanduiding van onheilspellende magte - al word dit versigtig gestel (bls. 64). In sy motiveringe is daar egter disharmonie. Op bls. 60 beweer hy „dat die Hebreeuse woorde in die res (my onderstreping, J.L.H.) van die Ou Testament nie so 'n onskuldige betekenis het" as die ongevormde toestand van die aarde voor die sesdaagse skeppingswerk nie. Verder: „Die fundamentele betekenis is: leegte, ydelheid, onbeduidendheid, nietigheid. Maar vir die Israeliet het hierdie begrippe 'n baie onheilspellender klank as vir ons Tohu kan die woestyn aandui, veral in sy afskrıkkende voorkoms... Dit is ook aanduiding van afgode en afgodsdienaars". Laasgenoemde stelling klop nie met die eerste nie: afgodsdienaars en veral afgode is nie onheilspellend nie. Jesaja wil in die betrokke gedeeltes juis sê dat daar niks van hulle te vrees is nie, dat hulle „nul" en „niks" is. Ons sou hier in elk geval 'n nadere verklaring van die gedeeltes oor afgode en afgodsdienaars moet hê.

In die bespreking van die Goddelike skeppingswerke van die verskillende dae, dring prof. Du Toit deur na die dieperliggende gedagtes en bring soms verrassende trekke na vore. Hy wys ook pragtig daarop dat dit in die Skrif nie net gaan om die hemelse saligheid nie, maar ook veral om die goeie skepping van God en gehoorsaamheid op hierdie aarde (bls. 80). (Myns insiens is dit egter te sterk gestel om te sê dat die Hebreeuse woord vir "goed" aandui dat dit beantwoord aan die doel waartoe God dit bestem het. Die basiese betekenis is volgens Koehler: „good in every variety of meaning", sodat die verband die nadere betekenis moet aandui.) Daar word telkens mooi verband gelê tussen skeppingswerk en Christus, waardeur die gedeeltes aan aktualiteit wen. Soms geskied dit egter sprongsgewys. Ons sou daarom ook graag die openbaringshistoriese lyn na Christus wou sien.

Baie mooi word gewys op die teologiese draagkrag van die refrein: „en God het gesê" en die betekenis van die „Woord" in verband met die skepping - met verwysing o.a. na Ps. 33 en Joh. 1. Hier word mooi perspektief gebied teenoor byvoorbeeld die beskouing van Lever (bls. 68). 
Oor die tuin van Eden word gestel: „Ons sal ons nou en in die naaste toekoms seker in steeds sterker mate moet afvra of dié deel van die klassieke voorstellingswyse, waarby die paradys gedateer, gelokaliseer en geindividualiseer gedink word, wel houbaar is". "Die tuin laat ons dus dink aan die hemel” (bls. 86). Dit is nie baie duidelik wat prof. Du Toit bedoel nie, maar dit skyn vir my of hy hiermee die grond onder sy eie voete wegneem in sy verweer teen die kaderopvatting oor Gen. 1 . Gen. 2 en 3 word tog net so „histories" (al sou dit histories-profeties wees) aangebied as Gen. 1: „, die HERE God het 'n tuin geplant in Eden, in die Ooste, en daar aan die mens wat Hy geformeer het, 'n plek gegee ..."

Dit is verwarrend as beweer word: „Ons gaan nie op al die besonderhede van Genesis 3 in nie maar slegs op wat God ons hier wil openbaar" (bls. 90). Is die res dan nie openbaring nie? Dieselfde beswaar geld van die stelling oor die huwelike tussen die ,seuns van God" en die „dogters van die mense” op bls. 107: ,Die verkondiging is duidelik: die mens het die deur God gestelde grense oorskry". Dit is seker nie al wat geopenbaar word nie. Die eerste vraag (as mens histories of histories-profeties dink) is seker: watter grense?

Die hoofstuk oor Die rasse- en volkeprogram in die heilsgeskiedenis, bied baie lig op die onderhawige sake. Die raak opmerking oor "die bekende opvatting waarvolgens die naturelle in ons land tot altyddurende knegskap veroordeel is" deur die profesie oor Gam, kan miskien verander word na ,'n bekende opvatting" (bls. 114). Dit kan moontlike misverstand en gevolglike veralgemening by Bantoes wat die boek lees, verhoed.

Die behandeling van die Dekaloog kan as goeie voorbeeld dien van hoe hierdie vierde uitgawe meer openbaringshistoriese vorm gekry het (bls. $138 \mathrm{vlg}$.). Daar word klem gelê op die inleiding en die raam van waaruit die Dekaloog verstaan moet word. Hier kan ook die bespreking van die eerste gebod genoem word. Besonder treffende gedagtes word in die bespreking van die afsonderlike gebooie na vore gebring. As die skrywer die terrein van die 0.T. oorsteek na die N.T., gee hy egter vir ons 'n vae en verwarrende bespreking van die verhouding van die Sondag tot die Sabbatsgebod (bls. 145-147). Van Calvyn word slegs 'n aanhaling uit sy kommentaar oor Gen. 17: 13 gegee waarvolgens sowel besnydenis as sabbat beëindig is toe Christus gekom het. Koole se opvatting word blykbaar as die regte voorgestel. Tereg word teen 'n identifisering van Sabbat en Sondag meer gewaarsku. Maar na die lees van 145-147 sit mens verleê met die vraag of die Sondag 'n menslike instelling van die vroeë kerk is, of 'n Goddelike instelling en feesdag. Het die Nieu-Testamentiese Kerk nog 'n Deka-loog of het hy net 'n Nova-loog? Mens stel jouself die vraag: moet ons so huiwerig wees om die „gebod"-karakter van die Evangelie na vore te bring?

Dit dien vermelding dat die skrywer oral die kontinuiteit van die openbaring aandui en byvoorbeeld wys hoe by Moses, die konings en ook by die profete telkens verband met Abraham, ,die vader van gelowiges", gelê word. Hy wys mooi op die rampspoedige gevolge 
van 'n oordrewe priesterlike religie (bls. 68), maar hy stel dit te radikaal as hy beweer dat ,daar 'n fundamentele verskil tussen profetiese en priesterlike religie" is; veral as hy hierdie stryd tussen profeet en priester terug voer tot by Moses. Was dit die priester (Aäron) as sodanig teen die profeet (Moses) as sodanig, of was dit geloof teenoor sinkretisme? Die profete het hulle alleen teen die verabsolutering van die priesterdiens gerig. Hierdie waarheid spreek des te sterker waar die Bybelkritiek vroeër 'n radikale verskil tussen profeet en priester gemaak het, maar vandag al meer erken word dat die profete in der waarheid oor die algemeen 'n noue verbintenis met die kultus gehad het. Net soos wat daar oppervlakkige en valse priesterdiens was, was daar ook 'n oppervlakkige en valse profetiese diens. Die lydende Kneg in Jesaja het profetiese en priesterlike trekke. Christus is profeet en priester (en koning).

Hoofstuk 10 gee $0 . a$. 'n inleiding tot die profete wat help om hulle verkondiging binne die betrokke raamwerk te sien. Die betekenis van die profete vir die geskiedenis van Israel en die openbaringsgeskiedenis word duidelik na vore gebring. Die probleem van die datering van byvoorbeeld die tweede deel van Jesaja word uitstekend omseil met die opskrif: „profesieë met die ballingskap en die gevolge daarvan as agtergrond". Besondere aandag word gewy aan Daniël en die lig wat sy profesieë op die wêreld- en openbaringsgeskiedenis werp. Hier word die koninkryksgedagte duidelik en spontaan na vore gebring. Dit verleen sodoende 'n treffende hoogtepunt aan die boek wat afsluit met die Volheid van die tyd en beklemtoning van die esgatologiese element in die openbaring.

In die tweede gedeelte is veral die bespreking van Die misterie van die volk Israel aktueel - bygewerk tot op datum.

Ons sou nog graag iets oor die poëtiese en wysheidsliteratuur en hulle openbaringshistoriese betekenis wou gehad het. 'n Lys van uitgesoekte werke vir verdere studie sou ook vir student en dosent handig te pas kon kom. Maar ruimte en koste is seker die belangrikste probleem.

Ons wil prof. Du Toit bedank vir hierdie deeglike, verrykende en prikkelende werk. Mag dit ons sowel as homself stimuleer tot verdere bepeinsing - ook oor die genoemde problematiese punte. En mag ons dan in 'n volgende uitgawe ook daarvan voordeel trek.

J. L. Helberg.

III. DIE „WOES EN LEEG” EN DIE „DAG”. (Reaksie op die bydrae van prof. J. L. Helberg, "In die Skriflig”, Junie 1969).

Met toestemming van die redakteur wil ek nog 'n poging aanwend om helderheid in ons gesprek te verkry. Dit is uiters noodsaaklik in die huidige teologiese konstellasie. 
veronreg het deur te spreek van „geesverwante" van hom. As ek hom daarmee leed aangedoen het wil ek graag verskoning vra. Dit was nie die bedoeling nie.

Ek sien $H$. nie graag as iemand wat simpatiek staan teenoor sekere teologiese tendense wat na my vaste oortuiging op verstarring afstuur en ernstige bekommernis wek ten opsigte van die toekoms van die Gereformeerde teologie.

Sonder dat ' $n$ mens dit besef dryf jy egter soms in 'n sekere rigting. In IDS (April 1968) het ek reeds gewys op reglynigheid en versekerdheid wat ek by $\mathrm{H}$. vind wat net so gev:iarlik is as die rigting wat so maklik „non liquet” sê. Renckens het tereg verklaar: Ons onderwerp is vol probleme maar voller van misterie. Self probeer ek oopstaan vir korreksie en het al 'n paar keer weer op sekere punte tot ander insigte gekom.

H. sal my miskien teëwerp dat hý bekommerd is oor die rigting waarin ekself (en geesverwante) gaan, dat ons eintlik afstuur op verwarring. Ons moet mekaar dus maar oor en weer reghelp. Daar is by my ten minste ' $n$ ernstige poging om sowel van verstarring as van verwarring weg te stuur, omdat die waarheid nie deur een van die twee gedien word nie.

\section{„Verskillende golflengtes"}

$H$. is blykbaar baie ontstemd omdat ek van „verskillende golflengtes" praat. Maar dit blyk tog telkens dat ons by mekaar verby praat. H. spreek bv. oor my opmerking dat daar nie veel hoop is dat ons twee mekaar op eksegetiese gebied sal vind nie en dat ons maar gedurig moet vra na die leiding van die Heilige Gees, om in hierdie moeilike vraagstukke as teoloë met die regte hermeneutiese beginsels te werk.

Daaruit maak $H$. die (m.i. ongeregverdigde) afleiding dat die oplossing vir my nie ' $n$ eksegetiese gesprek is nie maar ' $n$ gebed om die regte hermeneutiese beginsels. Die afleiding is heeltemal verkeerd, omdat hermeneutiek en eksegese altyd saamgaan. Daar kan nooit suiwer eksegese wees sonder die regte hermeneutiese beginsels nie. Dit is dus absoluut ongeregverdig om te sê: per slot van rekening moet die eksegese beslis. Ons vra: ook dié eksegese wat eerlik oortuig was dat die aarde op pilare staan? Hier was tog definitief 'n verkeerde hermeneuse werksaam.

Natuurlik is daar 'n wisselwerking en moet die beginsels van die Skrifverklaring uit die Skrif self gehaal word. Verder, ons moet ten minste eers weet wat die Skrif vir ons is, en hier speel die dogma ook weer 'n rol.

Dit is dus ' $n$ onverdiende beskuldiging dat ek my verantwoordelikhede ten opsigte van die eksegese na die terrein van die gebed wil verlê en 'n monoloog wil voer.

\section{„(Nuwe) hermeneutiese beginsels"?}

Die angel sit ook in hierdie geval in die stert. H. spreek van „prof. Du Toit se (nuwe) hermeneutiese beginsels wat so 'n verskil 
in golflengte bring dat daar nie meer eksegeties 'n gesprek moontlik is nie". Dít is dus die rede waarom ek $H$. nie kan verstaan nie!

Moet 'n mens nie darem ook by jouself so 'n bietjie skuld soek nie?

Wat die woordjie „nuwe" betref (darem nog in hakies) - in die lesing voor die onlangse saamtrek van predikante is my standpunt baie breedvoerig uiteengesit, naamlik: die Gereformeerde Skrifverklaring het gedurende die sewentiende en agtiende eeue onder invloed van die Skolastiek weggebreek van die suiwer Reformatoriese beginsels en prakties teruggevoer na die Middeleeue. Hierteenoor bepleit ek 'n terugkeer na die Reformatoriese beginsels. As dit nuut is, is ek bereid om die woordjie "nuwe" te aanvaar.

\section{„Teologiese geladenheid"}

$\mathrm{H}$. meen dat ek myself weerspreek deur eers te objekteer teen die gedagte dat die "dag" in Gen. 1 "teologies gelaai" is en daarna weer (skynbaar) volledig met hom saam te stem. Die leser sal opmerk dat ek liewer wou spreek van „openbaringsmatig" i.p.v. "teologies", omdat die teologie 'n wetenskap is en die Bybel nie wetenskap in tegniese sin bevat nie.

Die skynbare ooreenstemming tussen ons toon egter juis die radikale verskil aan. Juis omdat daar 'n "Goddelike geladenheid" in die woord „dag" is, kan dit nie so „eenvoudig" verklaar word soos $H$. wil nie, d.w.s. as 'n etmaal (wat in verband staan met die aswenteling van die aarde).

\section{„Denkklimaat”}

$H$. verklaar dat ek in my reaksie te ,selfversekerd is dat ek self van 'n denkklimaat vry is". Dit mag wees, maar dan moet bewys gelewer word. Ek verbeel my dat ek maar net in die Bybelse denkklimaat wil lewe en as teoloog sulke hermeneutiese beginsels wil toepas as wat werklik die volle rykdom van die Godsopenbaring na vore kan bring, terwyl ook aan die bevindinge van die wetenskap die plek gegee word wat daaraan toekom - in die lyn van Herman Bavinck.

\section{Die „woes en leeg"}

$\mathrm{H}$. beweer dat ek die duisternis (as iets „unheimisch”) verselfstandig teenoor die lig. Hy haal an uit Bybel-Skepping-Evolusie (1e en $2 \mathrm{e}$ uitgawes). Op bl. 168 van die tweede uitgawe staan egter duidelik dat tohu ens. onheilspellende magte ",aandui", nie "is" nie. Op bl. 187 word die volgende woorde van Koole aangehaal: "Waarskynlik kan 'n mens nog 'n stap verder gaan: dat Psalm 8 juis van die naghemel spreek, sal tot uitdrukking wil bring dat Jahwe sélfs die duisternis beheers". Dus - die duisternis is nie 'n selfstandige mag nie. In die eerste paragraaf op bladsy 55 (I.D.S. Junie 1969) toon $\mathrm{H}$. dat hy nie goed gelees het wat verderaan in Bybel, Skepping, Evolusie staan nie! Hy sê naamlik: „Dit gaan nie daarom of daar 
Dit wil my voorkom of ek my beter kan vereenselwig met 'n vroeëre uitspraak van H. In IDS (Aug.-Sept. 1967) kom hy naamlik (nadat hy die grootste gemene deler van drie tekste gevind het) tot die bevinding dat die "Dag" in die "Dag van Jahwe" in besonder 'n epogmakende gebeurtenis is en nie 'n temporeel-teleskopiese nie. Trouens, in die eerste uitgawe van BSE is die "teleskoopgedagte" van Progressive Creation reeds prysgegee en vervang deur die „profeties-historiese", waarin chronologiese en saaklike orde mekaar dikwels afwissel. Maar dan moet ons ook afsien van enige poging om die lengte van die dae te bepaal en moet $H$. sy „etmaal"-gedagte laat vaar.

As die skrywer hiervan Sauer aanhaal ten effekte dat die bedoelinge van God ver bokant die begrippe van die skrywers uitgegaan het; dat die skrywer van Gen. 1 moontlik aan ons gewone dae kon gedink het, maar dat die Gees daarmee "dae van God" bedoel het wat anders as ' $n$ etmaal is, dan sê $\mathrm{H}$ : ,goed, maar die skrywers sal nie in teenstelling met die Heilige Gees spreek nie". Ons vra: „is dit dan 'n teëstelling, iets anders, as die skrywer spreek van „dag" (moontlik soos hy dit ken) en die Gees bedoel 'n dag van die Here, waarin duisend jaar vir Hom soos een dag is? Dan is Ramm se woorde ook nie so onsinnig as wat $\mathrm{H}$. wil voorgee nie, as hy naamlik vra: "Kan by 'n „kosmiese dag" nie ook van aand en môre gespreek word na aanleiding van ons aardse dag nie?

Wat van Galleĩ ens.?

In my gesprek van April-Mei 1968 het ek gesê dat die tradisionele verklaring van Gen. 1 wel die maklikste weg is, maar of dit verantwoord is, is 'n tweede vraag, omdat dit gewetenskonflikte opwek.

Ek het o.a. die geval van Galileĩ genoem, maar $\mathrm{H}$. het dit blykbaar nie die moeite werd gevind om daarop te reageer nie. Hier was 'n duidelike geval waar die natuurwetenskaplike ontdekkinge ons geleer het om anders te eksegetiseer, soos tereg deur $\mathrm{H}$. Bavinck opgemerk is (vgl. sy Dogmatiek*, p. 458, 459.

$H$. hou egter vol: ,die eksegeet mag nie ter wille van harmoniëring met natuurwetenskaplike of ander wetenskaplike teorieë die teks rek nie". Ja, teorieë is gevaarlik maar dat die aarde om die son draai en om sy eie as, asook dat dit rond is en nie rus op pilare nie, behoort sekerlik nie meer tot die teorieë nie.

Ook op my opmerkinge in verband met die teorie dat die hele aarde paradys was voor die sondeval van die mens, kom $H$. nie terug nie, sowel as op die vermelding van die bevindinge van geoloë dat groot diererasse reeds uitgesterf het voordat daar 'n mens was en dat heelwat meer tyd as etmale verloop het.

Vir verdere uitwerking van hierdie gedagtes wil ek verwys na BSE (2), bll. 135-218 waar breedvoerig op al die probleme ingegaan is, nie net op formele sake soos $\mathrm{H}$. beweer nie. As daar nog onduidelikheid is moet ons maar op 'n keer 'n mondelinge gesprek voer.

Ek wil afsluit met die volgende woorde van L. F. Schulze: „Die epigone van Luther en Calvyn het in hulle toespitsing van bepaalde 
nou bose magte is wat teëgehou word nie, maar wel of die demoniese magte sekondêr is en eers ná die skepping in die geskiedenis 'n plek gekry het, en of hulle 'n primêre plek het, op basiese vlak, skeppingsvlak".

Op bl. 171 van BSE (1968) word teenoor A. Noordtzij deur skrywer hiervan gesê dat hy sou verkies om te spreek van „stryd na die (eerste) skepping". Let ook op hierdie woorde wat gevind word op bl. 176 van BSE (2): „Indien ons geen dualisme wil aanvaar nie (goed en kwaad beide ewig) moet ons daarmee rekening hou dat die sonde een of ander tyd na die skepping van God sy intrede gedoen het en dat volgens die Skrif Satan die ou slang is, die mensemoordenaar van die begin af, die god van hierdie wêreld ( 2 Kor. 4 : 4)". Dus - geen primêre plek aan die demoniese magte op Skeppingsvlak nie, maar daarna - in elk geval voor die sondeval van die mens.

\section{„Vorm-materie-skema"}

$H$. het die „woes en leeg" verstaan as „onherbergsame vorm. loosheid". In verband hiermee het ek gevra: "Kom dit nie miskien uit die vorm-materie-skema van die Wysbegeerte nie?"

$\mathrm{H}$. voel hieroor erg ontevrede. Hier het ek my laat lei deur Berkouwer en Dooyeweerd. Eersgenoemde wys ook die tradisionele verklaring van Gen. 1:2 af (De Zonde I, p. 82). Saam met Dooyeweerd verwerp hy die aanwending van die Griekse vorm-materie-skema in die verklaring dat die skepping eers vormloos is en dan deur die "formasie" vorm kry. 'n Mens kan ook die vraag stel: hoe is iets wat vormloos is? Selfs die ongeskeie massa het tog 'n vorm sonder vorm is dit ondenkbaar.

\section{„Die dae"}

H. beroep hom op teoloë soos Von Rad, Skinner en Simpson wat verklaar dat die skrywer van Gen. 1 aan niks anders as ons gewone dae gedink het nie. Self het ek, saam met ander, die moontlikheid toegegee dat die geinspireerde skrywer nie die draagwydte van die woord "dag" deurgrond het nie, maar dat die Heilige Gees iets veel rykers bedoel het. Manne soos die drie bogenoemdes sal egter nie skroom nie om te sê dat die Bybelskrywer dit heeltemal mis het maar waar beland ons dan? M.i. is dit dus vir H. gevaarlik om hom op hulle te beroep.

Hy verwys ook na die gedagte van $\mathrm{N}$. H. Ridderbos wat sê ,gewone dagen maar niet werkelijke dagen".

Dit is egter baie maklik om van "gewone dae" te spreek wanneer jy dit as „nie-werklike dae” opvat, d.w.s. as Gen. 1 ons slegs 'n kader of skema gee, soos Ridderbos wil. Die gedagte is dan dat die skrywer wel spreek van 'n dag maar dat aan sy spreke geen werklikheid beantwoord nie, in elk geval nie 'n etmaal soos $\mathrm{H}$. wil nie.

$\mathrm{H}$. dink in 'n goeie rigting as hy sê dat hy nie die moontlikheid verwerp dat die skeppingsdae van God langer as $6 \times 24$ uur geduur het nie. 
opvattinge van beide, al verder uitmekaar gegaan en verstar in die ortodoksie. Om sinvol kinders van die Reformasie te wees beteken wel om ook Luther en Calvyn se geloof biddend na te volg: biddend dat God sy Woord ook vir ons meer en meer sal open sodat die gesag van die Skrif lewende en beleefde werklikheid word (IDS April-Mei 1968, p. 9).

S. du Toit.

\section{HERMENEUSE-EKSEGESE}

Ek het die diskussie tussen professore S. du Toit en J. L. Helberg oor Genesis $1-3$ met groot belangstelling gevolg. Graag noem ek 'n paar punte wat m.i. nie altyd na wense verdiskonteer is nie.

\section{Die hermeneutiese sirkel}

In die gesprek het dit o.a. gegaan oor eksegese en hermeneutiek, en is beweer (prof. Helberg) dat ,per slot van sake moet die eksegese tog beslis - anders is die hermeneutiese beginsels menslike skemas en voorveronderstellings en nie neerslag van eksegese nie" („In die Skriflig”, Junie 1969, p. 56). Dit is nl. die vraag of hiermee die ontsaglik moeilike verhouding tussen eksegese en hermeneutiek nie té simplisties voorgestel word nie. Want hoe doen ons eksegese van die Heilige Skrif? Deur gebruik te maak van die juiste hermeneutiese reëls! En waar kry ons die juiste hermeneutiese reëls? Deur 'n korrekte eksegese! Juiste eksegese word dus gedoen met behulp van juiste hermeneutiese reëls nádat hierdie reëls deur 'n juiste eksegese gevind is! Hierdie sirkelredenasie is onontwykbaar vir elkeen wat die verhouding tussen eksegese en hermeneutiek minimaliseer of simplifiseer.

\section{Die hermeneutiese sleutel}

Die vraag is dus hoe ons ooit uit hierdie skynbaar onoplosbare dilemma kan ontsnap. Die Roomse teologie los die probleem ekklesiologies op: die tradisionele kérklike interpretasie is dié interpretasie (al moet ons na "Dei Verbum” ook die Roomse Kerk nie ongenuanseerd veroordeel nie). Met hierdie visie het die Reformasie geheel en al gebreek: sola Scriptura! Maar hierdie sola Scriptura is egter nooit op formalistiese wyse hanteer asof dit om die Bybel sou kon gaan losgemaak van die boodskap daarvan nie. (Dit is bekend dat Luther op hierdie standpunt selfs tot verstrekkende (Skrif-)kritiek gekom het). Die sentrale boodskap van die Bybel is nie, ongenuanseerd, Jesus, of: Christus nie, maar „Jesus is die Messias, die Seun van God" (Matth. 16:16, Hand. 17: 3), „Jesus is die Here" (1 Kor. $12: 3$, Filipp. $2: 11$, Hand. $2: 36$ ). Hy is die Gekruisigde (1 Kor. $2: 2$ ) en die Opgewekte (Rom. $10: 9$ ). Die apostel Johannes het sy hele lange evangelie vir hierdie (geloofs-) doel geskrywe (Joh. $20: 31$ ). Die Heilige Skrıf, ook die Ou Testa- 
ment, moet dus Christologies (nie Christomonisties nie) geinterpreteer word. Ten opsigte van „Moses" het die Here Jesus Christus ook Self die weg gewys: „Maar as julle Moses geglo het, sou julle My glo, want hy het van My geskrywe" (Joh. 5:46). Uitgaande hiervan kan ek persoonlik nie sien hoedat ons oor ,Moses", dus ook oor Genesis 1-3, 'n enkele sinvolle woord kan spreek buite Jesus Christus om nie (vgl. ook Joh. 1:3, 1 Kor. $8: 6$, Hebr. $1: 2$ ). Juis hiérdie fundamentele eksegetiese reël ontbreek $\mathrm{m}$.i. te veel in die bovermelde diskussie, as gevolg waarvan die hele gesprek dreig om te versand in 'n intellektualistiese woordespel.

Die hermeneutiese probleem kan m.i. slegs opgelos word in onlosmaaklike en vrugbare samespel - sónder 'n konkurrensieteologie! — van Bibliologie (Joh. $17: 17$ ), Christologie (Joh. $14: 6$ ), Pneumatologie (Joh. $14: 17,16: 13$ ) én Ekklesiologie (Joh. $16: 13$, Ef. $3: 18$ ). Dit is trouens die Heilige Gees wat die kerk (waarby ingeslote teoloë) in die hele waarheid (van die Woord, soos gesentraliseer in Jesus Christus) lei. En alleen „met al die heiliges" (ekumene!) begryp ons ten volle "wat die breedte en lengte en diepte en hoogte is, en die liefde van Christus te ken..."

Ten slotte lyk my die gedagte as sou die natuurwetenskap 'n voortdurende bedreiging vir die teologie inhou, ongegrond te wees. Dit neig na duoteīsme, waardeur twee gode aanvaar word: een van die Bybel en een van die natuur. Omdat dit egter eén God is wat Hom sowel in die Skriftuur as natuur openbaar (N.G.B. art. 2), kán daar geen sprake wees van 'n bedreiging nie. Hoogstens kan daar sprake wees van 'n wedersydse „bedreiging" van die interpretasie van die Skriftuur én natuur, maar dit beteken nie dat die natuur. wetenskap ingevoer word as 'n ,nuwe hermeneutiese reël" nie. Wie egter 'n onfeilbaar-gestolde interpretasie van die Heilige Skrif ten opsigte van periferiese aangeleenthede aanvaar, het daarmee die reformatoriese teologie en kerk op sy kop geplaas (N.G.B. art. 7). Wie egter tot 'n nuwe standpunt gekom het, strydig met dié van die Belydenis, is egter verplig om die kerkregtelike weg te gaan (gravamen).

Julie 1969.

J. H. van Wyk 
V. RONDOM 1866. Versamen deur ds. F. G. M. du Toit. Uitgesoekte tekste van Dokumente en Ander stukke m.b.t. Kerklike Ontwikkeling, veral in Transvaal. N.G. Kerk Boekhandel, Pretoria (1969). Prys R2.75.

Hierdie publikasie verskyn in opdrag van die Kommissie vir Historiese Navorsing van die Ned. Geref. Kerk se Sinode van Suid- en Noord-Transvaal. Dit wil hoofsaaklik dokumente rondom 1866 publiseer. Die Argivaris sê: „Vanuit die bronne kan die geskiedenis vir homself spreek" (voorwoord).

Ongelukkig is hiermee saam, feitlik as inleiding, gepubliseer „Eeufees van die Eerste N.G. Sinode”, deur dr. Wm. Nicol, „Ter herdenking aan 4 Desember 1866" deur dr. G. D. Scholtz en „Ds. Frans Lion Cachet - Sy rol in die jaar 1866" deur ds. F. G. M. du Toit. Hoewel laasgenoemde artikel beter is as die eerste twee, doen hierdie artikels afbreuk aan die bronnepublikasie "Rondom 1866", omdat dit dadelik 1866 in die kader van 1969 plaas. Die artikel van dr. Wm. Nicol kan moeilik as 'n historiese artikel kwalifiseer. Hy gee in werklikheid 'n apologie vir die Ned. Geref. Kerk, veral teenoor die Ned. Herv. Kerk, wat hy „Van der Hoff-kerk” noem (p. 8). Hy sê dat Van der Hoff homself bevestig het, terwyl die Volksraad oudl. A. D. W. Wolmarans daartoe aangewys het. Hy praat van ,nuwe sinodes" wat onverwyld na die Hooggeregshofsaak in 1862 in Natal en Vrystaat gestig is (omdat sinodes vir hom kerke is). Die geskiedskrywing van Nicol en Scholtz is tendensieus. Dit is in baie opsigte gedoen met die wit-swart-skema. Die werklike verhouding van die Kaapse Sinode van 1836 teenoor die Groot Trek word verswyg. Tog wil Nicol (bl. 10) en Scholtz (bl. 18) voorgee dat die Ned. Geref. Kerk (in verband met die Kaapse Kerk) in 1842 gestig is deur eerw. Lindley wat hoegenaamd in geen verband met of opdrag van die Kaapse Sinode gehandel het nie. Hoe kon dit ook as die Voortrekkers destyds deur die Kaapse Sinode de facto gesensureerd was? Selfs ds. W. A. Krige, die eerste N.G. predikant wat in offisiële hoedanigheid na die O.V.S. gestuur was, mog nog geen sakramente bedien nie. Scholtz sê (bl. 19) dat die bediening van die Voortrekkers ,het in 1847 ook die aandag van die Sinode geniet" asof dit die natuurlikste saak ter wêreld was. Die feit is egter dat hierdie Sinode 'n ander houding as die Sinode van 1836 aangeneem het. Daarna het offisiële bedieningskommissies na Transvaal gegaan. Dit is dus ook ' $n$ verkeerde voorstelling wanneer Scholtz sê: „,Die Voortrekkers het gehoop om 'n predikant uit die Kaap-kolonie te kry, maar dié was nie te vind nie" (p. 18). Die feit was dat hulle nie toegelaat was om te gaan nie (vgl. Sinode 1936 by A. Dreyer ,Die Kaapse Kerk en die Groot Trek" en „Die Voortrekkers en hul Kerk"; Korrespondensie van ds. J. Taylor van Cradock i.v.m. uitnodiging van die Potgieter- 
trek, ens.). Ek twyfel ook of "hartlikheid" (p. 20) die houding beskryf waarmee Andries Pretorius en sy mense na die slag van Boomplaas die Kaapse predikante in Potchefstroom die koue skouer gegee het, sodat Casper Kruger, vader van Paul Kruger, die Kommissie verder begelei het.

Die oor van die Gereformeerde historikus word deurgaans seer gemaak deur die kollegialistiese kerkbegrip wat in hierdie stukke aangewend word. Nicol het hom maklik afgemaak van die stigting van die Ned. Geref. Kerk t.o.v. die Geref. Kerk. Hy sê: „Intussen is die Gereformeerde Kerk in 1859 ook op Rustenburg gestig, maar dit raak die Ned. Geref. Kerk nie diep genoeg om hier bespreek te word nie" (p. 9). Die feit is tog dat die gemeente Lydenburg de facto verenig het met die Hervormde Kerk van Transvaal (vgl. o.a. die dokumente p. 36 e.v.). Ds. Cachet het toe ingegryp. Daarom word die eerste sinode eers in 1866 gehou, vandaar die publikasie "Rondom 1866". Indien dit in 1866 gegaan het om handhawing van die leer soos beweer word en Lydenburg na die hofsuitspraak van 1862 nie met die Kaapse Sinode meer kon verenig nie, waarom is 'n afsonderlike Ned. Geref. Kerk in Transvaal naas die Gereformeerde Kerk gestig? Nicol se eienaardige en subjektiewe pluriformiteitsopvatting wat kerke en sektes op een vlak plaas (p. 13 e.v.) verklaar nie die noodsaaklikheid van die stigting nie. Na my mening doen artikels wat so baie kritiek uitlok afbreuk aan die eintlike bronnepublikasie.

Hoewel die gepubliseerde dokumente in "Rondom 1866" hoofsaaklik die totstandkoming van die eerste Transvaalse Ned. Geref. Sinode in 1866 belig en vir die algemene kerkgeskiedenis beperkte waarde het, kan historici nou veel makliker toegang tot die dokumente verkry. Die publikasie is egter van groot kerkhistoriese belang en moet minstens die aandag van Suid-Afrikaanse kerkhistorici geniet. Dit moet opgeneem word in biblioteke t.o.v. S.A. algemene en Kerkgeskiedenis.

Pretoria, Sept. 1969

B. Spoelstra. 


\section{GEEN RUIMTE?}

Die voordragte van prof. dr. A. D. R. Polman, oor die gesag van die belydenisskrifte en die van die Heilige Skrif voor die G.T.V. op 2 September en die Teologiese fakulteit op 3 September 1969, wil mens nie loslaat nie. Die professor het die teenwoordige predikante en studente oorweldig met sy groot geleerdheid; die beheersing van sőveel kennis toegespits op die sentrale punt, wat ek wil noem: 'n versugting na meer ruimte vir die gereformeerde predikant en teoloog, was verstommend! Hoe kan so iemand, gevorderd in jare en een wat sy lewe lank behalwe Barth die hele teologiese litteratuur ,doorkropen heeft" en daarby die afgelope ses jaar alles wat die remonstrante geskryf het tot op die been deurvors het, weerspreek word deur manne só vér sy minderes? Die vanselfsprekende is tog om jou gevange te gee, sy meerderwaardigheid te erken en dankbaar te wees vir die lig wat hy ontsteek het. En dit is so 'n „bevrydende" gedagte! Dan ontkom jy aan 'n „verstarde" denkklimaat om die progressiewe ruimtes in te sweef. Prof. Polman het immers die weg aangewys om ontslae te raak van die knellende belydenisband, waarmee die vaders ons kwel vanaf Dordt tot vandag toe deur die ondertekeningsformulier vir bedienaars van die Woord. Die ou ondertekeningsformulier moet oorboord - dit gun nòg die predikant nŏg die teoloog die nodige ruimte om aan die Kerugma van die bybel vir ons tyd reg te laat geskied. Ons moet 'n formulier kry waarin die „quia" sowel as "quatenus"-standpunt „gehonoreer" word. Dit sou die gereformeerde kerk verlos van die verstarring in dogmatisme om weer by die bron, die Heilige Skrif, uit te kom. Die ruimtes lok!

Kom ' $n$ mens in die nabetragting op die voordragte van prof. Polman sover, pak huiwering jou tog meteens beet en die vrae kom los. Toegegee: as geleerde en as voordragkunstenaar, wat met gloedvolle oortuiging meesleur is hy by verre die meerdere wat nie aangetas kan word deur die teëspraak van sy minderes nie. Tog het ek tot die oortuiging gekom dat selfs hierdie toegewing nie 'n uitvlug is om langer te swyg nie - dit sou roepingsontrou wees! Roepingsontrou, omdat na my oortuiging nie langer geswyg kan word terwyl die saad wat onder ons gesaai is ontkiem en uitgroei nie.

Nadere besinning oor die voordragte het my oortuig dat die stem wat prof. Polman laat hoor vir ons as gereformeerdes al minder die stem is wat bevryding waarborg en die weg na die ruimtes aanwys. Al meer hoor ek die onverbloemde gekras van dic verleier, oorweldig deur die eie hartstog daarin!

Op die oog af is Polman - en ek glo dit is hom erns - besig om as vurige kampvegter vir die énige gesag van die Heilige Skrif op te tree. Die Heilige Skrif is die enigste reël van die geloof! Maar 
- en juis hierin is die eerste groot gevaar van sy quia-quatenusstandpunt verskuil - die gesag van die Heilige Skrif word ook reeds nader gekwalifiseer. Die kerugma van die Skrif of liewer die gekerugmatiseerde geskiedenis soos dit deur die bybelskrywers aan ons oorgelewer is, moet weer die alleenseggenskap kry. Daar mag geen sodanige binding aan ' $n$ historiesverankerde menslike interpretasie van die kerugma van die bybel in die belydenisskrifte wees dat nie gekom kan word tot 'n eie-tydse, selfstandige en vir die mens van ons tyd aanvaarbare deurgewing van die kerugma nie. Die gevaar lê juis in die wyse waarop Polman, nadat die belydenisskrifte ontkrag is, die bybel as enigste maatstaf proklameer.

Die weg is so gebaan vir ' $n$ onbelemmerde begrensing van die Skrifgesag deur die opvatting dat die bybel die gekerugmatiseerde geskiedenis, oorgelewer deur die bybelskrywers, is. Dit kom tog daarop neer dat die bybel uitgelewer word aan elke teoloog en predikant om self te bepaal wat die kerugma, ontdoen van die „verpak. king" is, en wat nie! Eintlik sal die wetenskap die deurslag gee van wat die eietydse aanvaarbare kerugma moet wees. Polman se verlange na 'n formulier wat sowel die "quia" as die "quatenus" honoreer maak nie net ruimte nie, dit lei na die absolute willekeur van die subjektivisme, soos reeds weerspieël in die nuwe teologiese rigting van gereformeerdes in Nederland.

Die Woord van God: die "So sẽ die HERE”, word vervang deur die „so sê ek": teoloog en dominee só en só! Die bevryding wat Polman bied en aanvanklik so aanloklik lyk, loop nie uit in die ruimtes nie maar in die gevangenis van die subjektivisme, onder die tirannie van die wetenskap.

Die nadenke oor die versugting na 'n „quia-quatenus"-formulier lê egter die valse uitgangspunt van Polman bloot. Die quia-standpunt van die ou ondertekeningsformulier sou dan oorsaak wees van 'n verstarring in dogmatisme. Is dit egter werklik so? Ontbreek die ruimte, wat elke gelowige teoloog nodig het om met oorgegewe aandag net te luister na die Skrif, werklik in die huidige formulier? Wie die formulier onbevooroordeeld lees, word juis getref deur die vryheid om enige tyd die "so sê die HERE" te proklameer teenoor elke willekeurige gedagtespinsel van mense wat in die belydenisskrifte mag ontdek word. Wat wel ontbreek is die ruimte om die gesag van die Skrif self aan te tas en aan die kerk willekeurig allerlei persoonlike opvattinge op te dwing!

Die predikant en teoloog wat die formulier onderteken het die volle vryheid, selfs plig om die gesag van die bybel - ook teen die dogma in, as dit moet - te laat geld. „Bedenkings” of „'n ander gevoele teen hierdie leer" word nie summier belet onder dreiging van skorsing en afsettings nie. Alle geleentheid word gegee om dit bekend te maak en te laat toets aan die enige maatstaf, die Woord van God, deur die bevoegde kerklike vergaderings. Daar is soveel ruimte dat wie die bestaande belydenis as uitgedien beskou, met 'n heeltemal nuwe te voorskyn kan kom - mits dit eis van die Woord is; en mits die profeet hom aan die ,reël vir die profete onderwerp! (1 Kor. $14: 29-33$ ). Polman se pleit vir 'n quia-quate- 
nus?-formulier - dink aan sy afsku vir 'n gravamen - het juis as opset die ontduiking van die reël vir die profete en daarmee baan hy die weg vir elkeen om sy eie „belydenis” willekeurig aan die kerk op te dring.

Geen ruimte? Nee - genoeg ruimte vir elkeen wat net wil luister na die "So sê die HERE", maar - en dit bly ons behoud - tog stewig gebind is deur die ondertekeningsformulier aan die reël vir die profete, sodat verhoed kan word dat die dienskneg self heer gaan speel!

G. P. L. van der Linde.

Bloemfontein, 20.10.1969.

\section{LITERATUUR}

Uitgangspunt van die artikel is die voordragte van prof. Polman, maar ck vestig tog die aandag op enkele belangrike werke wat op die onderwerp betrekking het en mee rekening gehou is in bostaande artikel.

1. D. Nauta: De verbindende kracht van de Belijdenisschriften.

2. H. Volten: Rondom het belijden der kerk.

3. J. Schelhaas: De Val van Assen.

4. F. W. Buytendach: Aspekte van die vorm/inhoud-problematiek met betrekking tot die organiese Skrifinspirasie in die nuwere gereformeerde teologie in Nederland. Ongepubliseerde Th.D.proefskrif, P.U. vir C.H.O.

5. H. van Riessen: Mondigheid en de Machten.

6. H. M. Kuitert: De Mensvormigheid Gods.

7. H. M. Kuitert. De realiteit van het geloof.

8. H. M. Kuitert: Verstaat gij wat gij leest?

9. Th. Delleman: Begin en Nieuw begin.

10. Th. Delleman: Alles Nieu.

11. Wording van mens en wereld (Th. Delleman).

12. Th. Delleman en ander: Nieuwe Commentaar Heidelbergse Kategismus 6 dele.

13. G. C. Berkouwer: De Heilige Schrift I en II.

14. G. C. Berkouwer: Verontrusting en Verantwoordelijkheid.

15. J. Lever: Creatie en Evolutie

16. J. Lever: Waar blijven we?

Verder verwys ek onder andere ook net na geskrifte van Baarda, Schippers, Rothuizen, Hartvelt en Koole. 